\title{
Divine fellowship in the Gospel of John: A Trinitarian spirituality
}

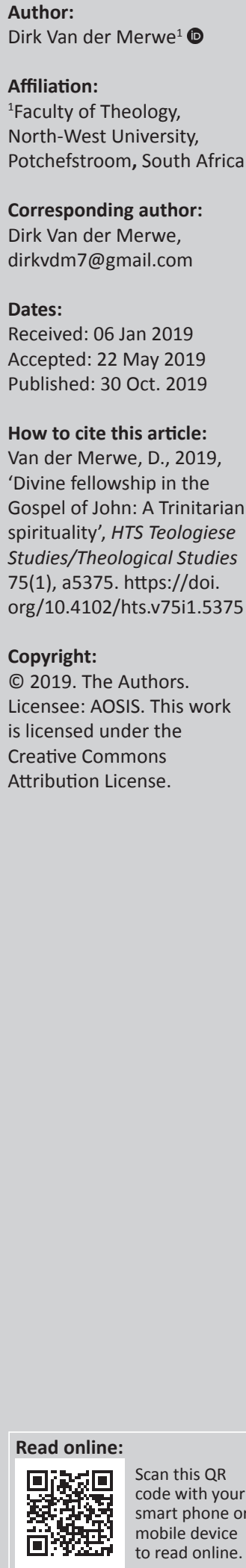

This article investigates how Trinity features are presented in the Gospel of John and how the early Christians experienced the Trinity in their daily lives. The immanence and 'lived experiences' of the divine are fostered by how the immanence of the divine is expounded in terms of the familia Dei: God as Father, the Logos as Son of God, believers as Children of God and the Spirit-Paraclete as the one who constitutes the family and educates the children in the family. Therefore, in this article, the familia Dei will be the facilitating hermeneutical principle used to examine the divine fellowship as well as the 'lived experiences' and immanence of the divine in early Christian everyday living. John's reflection on perichoresis lies embedded in a 'fellowship' perspective. The divine fellowship is investigated from the four perspectives of how the divine is identified in John: life in the familia Dei, love in the familia Dei, unity in the familia Dei and glorification in the familia Dei.

Keywords: Trinity; Divine-Fellowship; Familia Dei; Identity; Love; Life; Unity; Glorification.

\section{Introduction}

From the beginning of the early Church onwards, the early Christians embraced decisively exclusive monotheism and the veneration of Jesus. Both forms of Christian worship were already absolute when Christianity emerged from its original Jewish context (Bauckham 2008:294). Weiss (1937:I, 37; quoted by Bauckham 2009:232) called the emergence of the worship of Jesus 'the most significant step of all in the history of the origins of Christianity'. Just more than three decades later, Aune (1972:5) made a corresponding consent: '[p]erhaps the single most important historical development within the early church was the rise of the cultic worship of the exalted Jesus within the primitive Palestinian church'. For Hurtado (2003):

The accommodation of Jesus as recipient of cultic worship with God is unparalleled and signals a major development in monotheistic cultic practice and belief.

This variant form of monotheism appeared among circles who insisted that they maintained faithfulness to the monotheistic stance of the Jewish tradition. ${ }^{1}$ (pp. 53, 64)

After this statement, Hurtado (2003:53) further concluded that '[a]ny theory of the origins and development of Jesus-devotion must, therefore, grant a significant role to this monotheistic concern'.

Spinks (2008:31), in resonance with the above statements, extended to Jesus the sort of reverence reserved for the one God in biblical tradition. This reverence was not extended to any other figure. Indeed, the early Christians considered this reverence to Jesus as indispensable. Spinks located these views about reverence to Jesus in early Christianity as being reflected in the New Testament. ${ }^{2}$ John 5:23 is perhaps the most explicit expression of this attitude, declaring that according to God's will the Son should be reverenced $[\tau \mu \tilde{\omega} \sigma 1]$ analogously to the reverence of the Father, and that ' $[a]$ nyone who does not honor the Son does not honor the Father who sent him' (Jn 5:23, NRSV).

\footnotetext{
1.Prior the advent of Christianity, Judaism demanded the sole worship of its God. This was exclusive among the religions of the GraecoRoman world. Their perception of God has to be understood in terms of how they regarded the shema: 'Hear, O Israel: The Lord our God, the Lord is one' (Dt 6:4). Jewish monotheism was defined by its adherence to the first two commandments. The God of Israel was the one and only God. This implies that, because he was the sole Creator and only Ruler (supreme) of the universe, only He alone might be worshipped. This fixed Jewish monotheism, which condemned all other religions as idolatrous, also made Christianity an abhorrent be worshipped. This fixed Jewish monotheism, which condemned all other religions as idolatrous, also made Christianity an abhorrent oddness in the Roman world. This
God (Bauckham 2008:316-317).

2.To some extent, about 15 years after the crucifixion of Jesus, Paul the Apostle in the first chapter of his First undisputed letter to the Thessalonians already referred explicitly to all three members of the Trinity, God, the Lord Jesus Christ and the Holy Spirit, as being involved in the lives of the converts in Thessalonica. About two or three years later, he wrote in his undisputed First letter to the Corinthians, "Although there may be so-called gods in heaven or on earth - as indeed there are many "gods" and many "lords" - yet for us there is one God, the Father, from whom are all things and for whom we exist, and one Lord, Jesus Christ, through whom are all things and through whom we exist' (1 Cor 8:5-6), to summarise the distinctive nature of early Christian devotion.
}

Note: The collection entitled 'God as One', sub-edited by Erna Oliver (University of South Africa) and Willem Oliver (University of South Africa). 
Each of the canonical Gospels - Matthew, Mark, Luke and John - portrays an idiosyncratic picture of Jesus Christ. Individually, they present distinctive discernments of who Jesus is and what he accomplished. A comparison between these four canonical gospels exhibits both unity and diversity. Their witness concerns the same Jesus (unity) but, viewing him from idiosyncratic perspectives (diversity). In fact, it can be deduced that they, through their authors, express four unique 'lived experiences' (spiritualities) of Jesus.

'Matthew presents Jesus as the Jewish Messiah, the fulfillment of Old Testament' expectations (Combrink 1980:85; Strauss 2007:171-211); 'Mark portrays him as the suffering (Servant), Son of God, who offers himself as a sacrifice for sins' (Strauss 2007:213-258; Vorster 1980:131); 'Luke depicts Jesus as the Savior for all people. He conveys salvation to all nations' (Du Plessis 1980:171-172; Strauss 2007:259-296); and in John, Jesus is the Christ, eternal Son of God, the self-revelation of God the Father (Coetzee 1993:57; Strauss 2007:297-343; cf. Köstenberger 2013:23). What is important here is that these four perspectives (experiences) of Jesus complement one another.

In John, the veneration of Jesus is distinctly evident, ${ }^{3}$ and even the divine identity of the Spirit-Paraclete is acknowledged. For John, the three divine Persons are within themselves a 'familia Dei' prior to any inclusion of disciples of Jesus. These three divine Persons constitute by themselves a 'family' characterised by their 'lived experiences' of one another expressed as mutual 'life, unity, love and glorification'. This is the dynamism for John's understanding of who God is, and which explains Stamatovic's 'perichoresis's (Stamatovic 2016:304).

The choice of 'divine fellowship' in the title of the article is because of the fact that, in John, the three persons of the Trinity are predominantly discussed or depicted in relationship with one another. John relates the fellowship between believers and the divine to the fellowship existing within the divine (cf. Jn 17:21-23). John defends the fellowship within the divine (Trinity) in terms of the divine identity characteristics and their fellowship with God's children in the familia Dei: life, unity, love and glorification (cf. Kysar 2007:132-142). He uses his discussion of these characteristics in the lives of the children of God to reflect on the unity and fellowship in the divine. It will be pointed out that for John daily Johannine Christian living should mirror and reveal the fellowship within the Trinity. John describes divine fellowship in this way to convince his readers of the reality of Trinitarian spirituality and to facilitate their adoption of the same.

The modus operandi to be followed in order to examine the fellowship in the familia Dei will be, firstly, to briefly identify the identities of the Father, Son and Spirit as depicted in John.

3.According to Keener (2002:1, 310), '...the Fourth Gospel highlights Jesus' deity more than the other gospels'.

4.'According to the most common theological interpretation of perichoresis, it is an important notion of the Trinitarian theology that expresses the mutual indwelling and containment among the persons of the Holy Trinity - their presence in each other, in which each contains the other' (Stamatović 2016:304).
Secondly, a Trinitarian spirituality approach will look into these divine identity characteristics: life in the familia Dei, love in the familia Dei, unity in the familia Dei and, finally, glorification in the familia Dei. The fellowship that occurs within the Trinity (deduced from Jn 17:21-23, $\dot{\varepsilon} v$ and $\tilde{\varepsilon} v$ ) should become evident and experiential in the Johannine community (Jn 15:1-8,

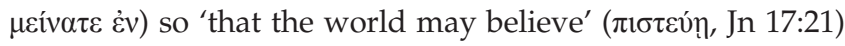

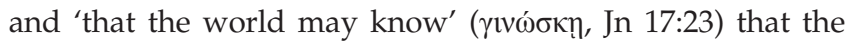
Father has sent the Son into the world.

\section{Perichoresis in the familia Dei}

When reading John, the reader is presented with the concept of monotheism as early as in the prologue. The author uses the singular form every time when referring to God: in John

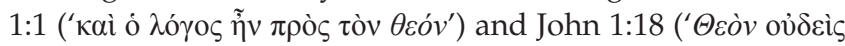

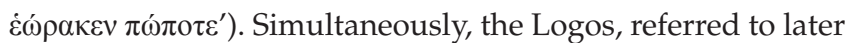
in the prologue as Jesus Christ and the one and only Son/

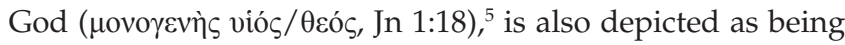
in a close relationship with God when he is referred to as God

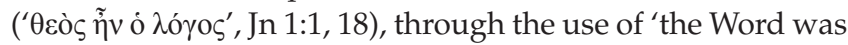

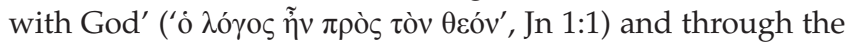

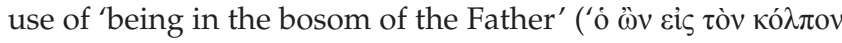

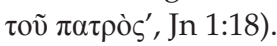

Then, at the end of the prologue, John states that 'nobody has ever seen ${ }^{6}$ God' $^{\prime}$ Jn 1:18; see also Jn 5:38; 6:46; 1 Jn 4:12, 20). If this is so, how can humans speak about or even communicate with this (monotheistic) God? John then, influenced by the Old Testament ${ }^{7}$ and the early Christian church, ${ }^{8}$ identifies God with 'Father' (Jn 1:18), Jesus as 'Son' (Jn 1:18) and believers as 'children of God' (Jn 1:12) to constitute the familia Dei in John. To become part of the familia Dei, people have to be born from God (by the Spirit, Jn 1:13; cf. also Jn 3:5, 6, 8). ${ }^{9}$ These metaphors not only objectify the divine ${ }^{10}$ but also enable believers to talk about the divine, to communicate with the divine and to experience the divine.

John further solves this problem in the apodosis of John 1:18 by referring to ' $[t]$ he one and only Son/God, ${ }^{11}$ who is in the

5.Textual criticism shows that either the "unique ( $\mu$ oovovevn's) God' or the "unique Son' has made the Father known. An analysis of the manuscript makes it very difficult to decide which reading is to be preferred. Irrespective of the choice, the theological implications are not much different. The strongest support favours the 'only God' in $\mathfrak{P}^{66}$, Sinaiticus, Vaticanus, and is similar to $\mathfrak{P}^{75}$ and 33 (the so-called queen of the cursive manuscripts). The variant, the 'only Son' is supported by Alexandrinus, $\theta, \psi$ and others. This reading seems to be the easier reading and could have resulted from an attempt to assert a father-son relationship. The first reading is more difficult and can be rsert a father-son difficult and can be regarded to be theologically more developed. Neither reading

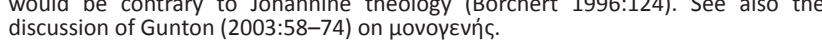

6.Davies (1992:120) interprets this remark to God to 'propose that God in himself is beyond the powers of human comprehension, because he is mysteriously different beyond the powers of human comprehen
from anything encountered in the world'.

7.In the Old Testament (OT), God is referred to as Father (Dt 32:6; 1 Ch 29:10; Ps 103:13; $\operatorname{Pr} 3: 12 ;$ Jr 3:19; 31:9; Is 63:16; 64:8; Ml 1:6; 2:10). In the OT, Israel is referred to as son/children (Ex 4:22-23; Dt 14:1; Ps 82:6; Hs 1:10; 11:1; Is 1:2). See also Van der Merwe (2014:1-9) on how John is saturated with Torah spirituality.

8.See only Paul's undisputed epistles: God as Father (Rm 1:7; 6:4; 8:1; 15;6; 1 Cor 1:3; 8:6; 15;24; 2 Cor 1:2); Jesus as Son of God ( $R m$ 1:4), his Son ( $R m 1: 9 ; 5: 10)$; his own Son ( $\mathrm{Rm} 8: 3$ ); believers as children of God ( $\mathrm{Rm} 8: 14,14,19,22 ; 9: 8)$.

9.This is one of the two most prominent themes in John. The other prominent theme in John is that of 'agency' (see Köstenberger 1998; Van der Merwe 1996).

10.In this essay, references to the 'divine' include the Father (God), the Son (Jesus) and the Spirit-paraclete.

11.See footnote 7 
bosom of the Father, He has declared Him'. The one and only

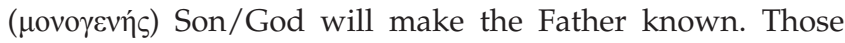
who accept the Son (Jn 1:12) will be born of God (Jn 1:13) into the familia Dei and become 'children of God'. The familia Dei then is constituted by God as Father, the Logos as Son of God, believers as Children of God and the Spirit-Paraclete as the one who constitutes the family and educates the children of God (cf. Van der Watt 2000). ${ }^{12}$ For John, the familia Dei constitutes the environment where God becomes reasonable and can also be experienced. The identity of the divine persons will now be discussed.

\section{The Father and the Son}

The most common metaphoric description for God in John is 'Father'. This noun occurs almost $120^{13}$ times in comparison with 'God' ( $\theta \varepsilon$ ós), which appears 108 times (Juel 1997:316; Reinhartz 1999:1, 6; Thompson 1999:24), all in the singular form. Davies (1992:120) expresses the term 'Father' the phenomenon, relation, and in John, especially relation to Jesus (and the children of God). This immediately made God knowledgeable and specifically experiential. In John, it is all about God (Father). God is uniquely the Father of the Son (Jesus). Most of the statements about God as Father include the role and identity of the Son, and vice versa. To speak of the Father is to speak of the Son; to speak of the Son entails speaking of the Father (Thompson 2014:155). God then is especially known in relationship to Jesus, as God is depicted as Father and Jesus as Son (Juel 1997:317).

The comprehension of God as Father in John requires a concentration on the 'relationship between the Father and Son' (Thompson 1999:20). The first reference to God as Father occurs as early as in the prologue (Jn 1:18). There, God is in

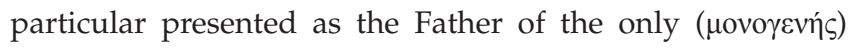
Son/God (Jn 1:18), which is also referred to as Jesus Christ in John 1:17. In two verses (Jn 1:14, 18; cf. also Jn 3:16, 18), the

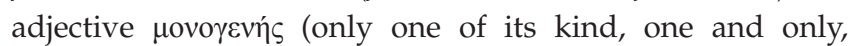
unique) (Danker 2000:658) highlights Jesus as being the only Son of the Father. All the other indications in John depicting God as Father come from Jesus. Jesus entitles God as 'my Father', even 'the Father', and idiosyncratically as 'the Father who sent me'. Also in editorial comments, John refers to God as Father where Jesus' exclusive sonship is on view. A good paradigm occurs in John 5:18. In this pericope (Jn 5:1-18), Jesus allegedly calls 'God his own Father, thereby making himself equal to God' (Jn 5:18; cf. Jn 8:27; Thompson 1999:19).

Articulations referring metaphorically to the Son as being 'sent' fits the 'Father' vocabulary in the Gospel - the Father sends the Son (Jn 3:16) and also the Holy Spirit (Jn 14:16, 26; cf. Jn 15:26). Similarly, for John, Jesus did not do 'the will of

\footnotetext{
12.In spite of the fact that there are no explicit 'Trinitarian' or even 'triadic' formula in John, there are passages and accounts that link the Father, Son and Spirit; for example, the Spirit comes down from heaven and remains on Jesus (Jn 1:32-33); those who believed in Jesus became God's children by being born anew of the
Spirit (Jn 1:12-13; 3:3-6); Jesus sends the Spirit (Jn 16:7), or Jesus asks the Father

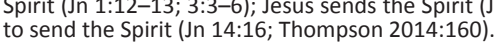

13.Both Juel (1997:316) and Reinhartz (1999:1) refer to a total of 118.
God', ${ }^{14}$ but the 'will of the Father' (Jn 4:34; 5:30; 6:38; 8:29 and $7: 18 ; 8: 50$ a by implication). When Jesus talks with God, he addresses him as Father. These references substantiate why $\pi \alpha \tau$ $\rho$ (Father) has become the most significant term, other than $\theta \varepsilon$ ò (God) itself, to refer to God.

Probably, the most fundamental verse in John to identify and characterise the Father comes from John 5:26, ${ }^{15}$ stating that 'the Father has life in Himself' (Thompson 1999:21). ${ }^{16} \mathrm{He}$ is the source of life. Three further characteristics of the Father include the following: he is the source of love, he is someone worthy of obedience and honour and he constitutes fellowship through unity. These characteristics have analogies with human fatherhood. This helps make the metaphorical (see Reinhartz 1999; Thompson 2001, 2014) fatherhood for God meaningful (cf. Koester 2008:48), comprehensible and experiential for human believers. After a brief discussion of the identity of the Spirit-Paraclete, these identity characteristics will be discussed.

\section{The Spirit-Paraclete}

John's gospel has more material on the Spirit than any other gospel, and the presentation of the Spirit is simultaneously more complex. That complexity may be summarised briefly: in Chapters 1-12 and 18-21, John speaks only of 'the Spirit' (thrice, of the Holy Spirit, Jn 1:33; 20:22; cf. Jn 14:26);17 in the Farewell Discourses (Ch. 14-17), Jesus talks about the Spirit as the Paraclete, the Spirit of Truth and the Holy Spirit, who will come after his departure. ${ }^{18}$

The identity of the Spirit-Paraclete in John can be reduced to three conceptions. Firstly, the Spirit-Paraclete has been perceived as a personal divine being distinct from both the Father and the Son, but also very closely identified with the Son. ${ }^{19}$ Secondly, the Paraclete-sayings communicate the recurrence and presence of Jesus. Thirdly, the Spirit is also perceived, along with 'Word' (New Testament) and 'Wisdom' (OT) to speak about 'God's activity or the continuation of Jesus' ministry' (cf. Thompson 2001:146 for a nuance variation).

14.In John 12:49 (see also Jn 12:50; 8:28-29; 14:10), Jesus says to his disciples, 'For have not spoken on My own authority; but the Father who sent Me gave Me command, what I should say and what I should speak'. Jesus speaks and does what was communicated to him by the Father. By doing so he glorified the Fathe (Jn 17:4, NRSV). For this researcher, this obedience of the Son is not a matter of (Jn 17:4, NRSV). For this researcher, this obedience of the Son is not a matter of Logos (Father and Son).

15.'For as the Father has life in Himself, so He has granted the Son to have life in Himself' (Jn 5:26).

16.The noun 'Father' often appears alone. Once the adjective 'holy' (Jn 17:11) is added and quite often the personal pronoun ' $m y^{\prime}$ (Jn 5:17; 6:32, 40; 8:19, 38, 49, $54 ; 10: 18,29,37 ; 14: 7,20,21,23 ; 15: 1,8,15,23,24 ; 20: 17)$. A few times the phrase 'who sent me' (Jn 5:37; 6:44; 8:18; 12:49) is added and the adjective 'living' (Jn 6:57) is added once. God is 'the living Father'. This phrase reflects the fundamental designation of God as 'the living God' (Thompson 1999:21).

17.John's reference to this Spirit as 'the Holy Spirit' (Jn 1:33) obviously implies the Spirit of the holy Father (Jn 17:11).

18.The language about the Spirit in John is significant to Old Testament usage. A close relationship occurs between the work of the Spirit whom the Father sends (and the Son also participates) and the work of Jesus that resonates with the 'will of the Son also participates) and the work of Jesus that resonates with the 'will of the
Father'. The God known to Israel is now also known and experienced through the continuing work of the Spirit whose activities are tied with the ministry of Jesus. The author and the disciples witnessed about it (Juel 1997:317).

19.Compare Dunn (1989:131) for a variant point of view. 


\section{Personal}

The Farewell Discourses in John (Ch. 14-17) provide the strongest substantiation for perceiving the Paraclete as a distinct, though divine character. In John 14:16-17, 26; 15:26; $16: 7,13$, he is portrayed not only as an independent agent but is also identified in relation to Jesus in all that he will do. The Spirit relates directly to $\operatorname{God}^{20}$ for the Spirit comes down from heaven (Jn 1:33; Thompson 2014:15). He is called Holy Spirit (Jn 1:33; 20:22; cf. Jn 14:26) which relates to Holy Father (Jn 17:11). The phrases involving the Paraclete, 'whom I will send to you from the Father' (Jn 15:26) and 'who proceeds from the Father', are a synonymous parallelism. Alternative phrasing is used to express the same idea (Beasley-Murray 1999:276; see also Schnackenburg 1982:III, 118). The Spirit who comes from above (Jn 3:6-7) enables people to enter and see the kingdom of God.

\section{Jesus is coming back}

A division in the Gospel of John can be drawn between Chapters 12 and 13. In the first part, the emphasis falls primarily on the descension of Jesus and, in the second part, it is primarily on his ascension. Prior to his Farewell Discourses, he had already said to his disciples that he was going back to where he had come from (Jn 13:1, 3, 20, 33, 36). In the same conversation, he also said that he would return to them..$^{21}$ According to these verses, Jesus promises that he is coming back to his disciples in the garment of the SpiritParaclete.

The Spirit is designated as 'another Paraclete' (Jn 14:16), where Jesus is referred to as being a 'Paraclete' in 1 John 2:1. Firstly, by calling the Spirit 'another $\pi \alpha \rho \alpha \dot{\alpha} \lambda \eta \tau \varsigma^{\prime}{ }^{\prime}, 22$ Jesus indicates that the presence of the Paraclete with the disciples will replace Jesus' physical presence with them (cf. Jn 14:17). ${ }^{23}$ When the Paraclete comes to abide in the disciples and existentially remain in them (Jn 14:17), it will be as if Jesus himself will dwell in them..$^{24}$ Therefore, Jesus could refer to

20.Thompson (2001:159), in contrast, argues that there is no explicit argument in John about how the Spirit relates to God.

21.Käsemann (1968) regards the Farewell Discourses as Jesus' testament for his disciples. The function and meaning of these references to the Spirit-Paraclete (Jn 14:15-17; 14:26; 15:26-27; 16:7-11; 16:13-15) address their situation. It assures the community 'that Jesus is not a mere memory but a real presence' (Shillington 2012:35).

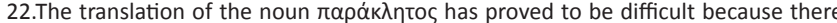
does not seem to be an exact equivalent in the English language. None of the expressions chosen in English translations seems fully adequate: 'Helper' (NKJV, NASB, ESV, ISV, NCV GNB). 'Advocate' (NRSV, NAB). 'Counselor' (NIV, RSV) NASB, ESV, ISV, NCV, GNB); 'Advocate' (NRSV, NAB); 'Counselor' (NIV, RSV) o Comforter, (KJV. See discus 'Adion (2013:141) and Köstenberger (2004:436). Perhaps the translation, 'helping presence', according to Köstenberger (2013:146), captures the importance of the term better than any other for the following reasons: '(1) this is what Jesus was while with the disciples; (2) this encompasses the various functions laid out for the Spirit in John 14-16; (3) this transcends (but may include) the legal context of the term (see esp. 16:7-11)' See the discussion by Ridderbos (1997:499-504) on Paraclete. After stating that the meaning of Paraclete can hardly be conveyed in one word, he appeals that the Johannine context (rather than alleged extrabiblical parallels) determines the

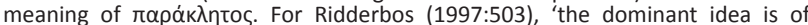
someone who offers assistance in a situation in which help is needed'.

23.Köstenberger (2004:436) quotes Talbert (1992:207) who calls the Paraclete 'an abiding presence', 'a teaching presence' and 'a presence that both guides into al truth and declares the things to come'.

24. Brown (1972:642) refers to the triadic indwelling of the divine in believers: '14:1524 includes the Spirit $(14: 15-17)$, Jesus $(14: 18-21)$ and the Father $(14: 22-24)^{\prime}$. Such a pattern is not unusual and occurs also in the Pauline writings (1 Cor 12:4-6; 2 Cor 13:14; Eph 4:4-6). See also Turner (1996:80). the coming of the Spirit as, 'I will come to you' (Jn 14:18; Köstenberger 2004:436). Secondly, just as God manifested his presence with the disciples through Jesus, similarly he will continue to be present with them through the Spirit-Paraclete. The Spirit thus participates in the continuation of the agency of Jesus. To talk about the Spirit-Paraclete is to talk about the resurrected Christ, and his presence.

The sending of the Spirit-Paraclete is described in complementary ways that point out the unity between the Father and the Son (cf. Jn 5:19-30; Carson 1991:499). The following section details a brief analysis of the Paraclete references, which is intended to point out the inseparable connection of the Spirit-Paraclete, primarily with Jesus and secondarily with the Father (cf. Koester 2008:147, 149, 150).

I will not leave you orphans; I will come to you. ${ }^{19} \mathrm{~A}$ little while longer and the world will see Me no more, but you will see $\mathrm{Me}$. Because I live, you will live also. ${ }^{20}$ At that day you will know that I am in My Father, and you in Me, and I in you. (Jn 14:18-20 $)^{25}$

You have heard Me say to you, 'I am going away and coming back to you'. If you loved Me, you would rejoice because I said, 'I am going to the Father', for My Father is greater than I. (Jn 14:28)

It is to your advantage that I go away; for if I do not go away, the Helper will not come to you; but if I depart, I will send Him to you. (Jn 16:7).

And I have declared to them Your name, and will declare it, that the love with which You loved Me may be in them, and I in them. (Jn 17:26)

\section{The activities of the Spirit-Paraclete as representation of the Father-Son}

The mission of the Spirit is in many matters parallel to the mission of the Son (cf. Jn 8:42; 13:3; 17:8). The primary task

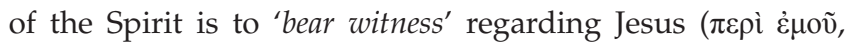
Jn 15:26; Beasley-Murray 1999:276). Bultmann (1971:553-554) points out that the witness borne by the disciples is not something secondary, running alongside the witness of the Spirit'. They conjoined to reveal the truth of Jesus' revelation via his words, deeds, death and his resurrection. The witness of the Paraclete does not occur apart from the witnessing of the disciples, but rather inseparably complements their witnessing. 'The Spirit is the power of the proclamation in the community' (see also Beasley-Murray 1999:277).

In 14:6, John refers to Jesus himself as the truth. A few verses later (14:17) he designates the Spirit as the (Carson 1991:539) 'Spirit of truth'. This Spirit will guide the disciples into all the inferences of the truth, the disclosure, inherently compelled with Jesus (Carson 1991:539). Just as Jesus never followed his own initiative, but cohered in word and deed what the Father imparted him to say and to do (Jn 3:34-35; 5:19-20; 7:16-18; 8:26-29, 42-43; 12:47-50; 14:10), so also the

25 After his reference about the Paraclete that "he abides with you, and he will be in you' (Jn 14:17), Jesus states that he and the Father will dwell among those who love him and obey his word (Jn 14:23; cf. Koester 2008:151). 'This implies that they love him and obey his word (Jn 14:23; cf. Koester 2008:151). 'This implies that they
will continue and duplicate the mission of Jesus who sends them, to continue the will continue and duplicate the mission of Jesus who sends them,
divine mission of the Father/Son' (Van der Merwe 1998:115-127). 
Spirit speaks only what he hears (Jn 16:14-15). As Jesus' allinclusive obedience to the Father confirms the very revelation of God himself, the Spirit analogously, by his dependence, ensures his unity with God and the revelation God graciously grants (Carson 1991:539). Jesus said that if the Spirit takes 'what is mine' and communicates it to the disciples, then the content of 'what is mine' implies and refers to the revelation of the Father himself (Jn 16:14). Therefore, Jesus could proclaim, ' $[a] 11$ that the Father has is mine' (Jn 16:15, NRSV). That is why Jesus has moulded the ministry of the Spirit-Paraclete in terms of the unfolding of what belongs to the Son (Carson 1991:541).

The Spirit of the living Father (Jn 6:57) also gives life (Jn 6:63; $7: 37-39 ; 20: 21-23)$. If Jesus has life in himself and confers it on others as a gift from the Father, so Jesus offers the Spirit because '[God] gives the Spirit without measure' (Jn 3:34). The Spirit generates the divine life given by the Father through the Son in those who come to faith (Jn 1:13; 3:5, 8; cf. Thompson 2014:160).

For John, an important attribute of the Spirit-Paraclete is that of a teacher (Jn 14:26) who will be with the believers, educating them in the familia Dei and reminding the disciples about the teachings of Jesus (Jn 14:26); he will testify on behalf of Jesus (Jn 15:26); he will accuse and convict the world (Jn 16:8-11) and he will glorify Jesus (Jn 16:13). ${ }^{26}$ This is the 'truth' constituting the 'Spirit of truth'.

The discussion will now return to the identity characteristics of the Father (shared by the Son) to be experienced, as a Trinitarian spirituality, by the disciples of Jesus and be embodied in their lives through the Spirit-Paraclete.

\section{Trinitarian spirituality}

\section{Life in the familia Dei}

For John it is axiomatic that the God of John is the same as the God of the Jews. For them, the account of God as 'the living God' serves in later Jewish monotheistic reasoning to emphasise 'the unity and uniqueness of God'. The phrase, 'the living God', does not appear in John although the variation, 'the living Father', occurs ${ }^{27}$ (Thompson 1999:22-23). Thompson (1999:23) points out that this variation is not incidental, rather it is an indication of a deliberate selection because of a conviction that this divine being alone is the source of all life. Life characterises God's identity. The key verse here is John 5:26: 'Just as the Father has life in himself, so he has granted the Son also to have life in himself'. While the Son has what the Father has ('life in himself'), the Son has it because the Father 'has granted' it to the Son; he can, in turn, confer that eternal life on others (Jn 1:12, 13; Thompson

26.In those sections of John where the reference to 'Spirit' dominates, the Spirit effects purification, true worship and life. 'In the Farewell Discourses, the Paraclete testifies to and glorifies Jesus, teaches and accompanies the disciples, and convicts the unrighteous' (Thompson 2014:159).

27.Thompson (1999:21) explains that the most fundamental characteristic of God is that he is eternal. Therefore, by implication, only he can be the source of life. This view resonates fundamentally with John's view of God as the life-giving Father. Therefore, John refers to him as 'the living Father'.
2014:157). He could do this with authority because the Father sent him to grant eternal life to humans. ${ }^{28}$

Within the context of Chapter 5, where the Jews accused Jesus making himself equal to God, this expression of life assumed their monotheistic belief that there is only one source of life. Jesus cannot be a second deity, he cannot be a second source of life, finding himself next to the Father. For John, the Father's life is awarded to the Son, which he consists in himself. How John formulated this, firstly, explains the unity that exists when the Father and Son bestow life, and secondly, it awards a significant position to the Son, a being that is not created by any other being. According to Barrett (1978:260), '[t]his expression, denoting exact parallelism between the Father and the Son, is the keynote of this paragraph' (Jn 5:22-30). The Son participates or is part of the same life of the Father: the Son 'has life in himself'. Therefore, when Jesus bestows life on those who come to faith in him, they also share in the Father 's life, for 'the Father has given the Son to have life in himself, even as he has it' (Grayston 1990:51, referred to by Thompson 1999:24).

These references to Jesus, constituting this divine life, verify the discussion so far: 'In Him was life, and the life was the light of men' (Jn 1:4); 'for as the Father has life in Himself, so He has granted the Son to have life in Himself' (Jn 5:26). Because the Word (the Son) has that 'life in himself' (cf. Jn 5:26), which is distinctive of God, the Word therefore is called God (Jn 1:1).

'He is the light that gives life' (Jn 8:12-20). 'I lay down My life for the sheep' (Jn 10:15); 'I lay down My life that I may take it again' (Jn 10:17). 'No one takes it from Me, but I lay it down of Myself. I have power to lay it down, and I have power to take it again' (Jn 10:18). He himself is the true life. This is clearly indicated in John through the various $\dot{\varepsilon} \gamma \omega \dot{\varepsilon}$ cì sayings: 'I am the bread of life' (Jn 6:35, 48), 'the resurrection and the life' (Jn 11:25) and 'the way, the truth and the life' (Jn 14:6).

The above predications presume that there is only one God, one source of life. John thus legitimates the Son with an extraordinary eminence, a predication not allotted to any other creature or being, either in John or in Jewish literature, namely, that there is one who has that which is unique to God (life in himself) and accordingly is what God is (living; and eternally living). The question that arises is, 'how they will experience this "new life" when the Holy Spirit, the third person of the Trinity, generates this "new life"'?

For John, the first task of the Spirit was to make Jesus known. This identifies the work of the Spirit later in the Gospel (Koester 2008:134). When the Baptist was interrogated by a delegation from Jerusalem whether he might be the Messiah, Elijah or the prophet, he rejected it and pointed at Jesus and says, 'Behold! The Lamb of God' (Jn 1:29). He then adds that without the intervention of the Spirit he would not have been

28 John 11:42: "I knew that you always hear me, but I have said this for the sake of the crowd standing here, so that they may believe that you sent me'. John 17:8, '... for the words that you gave to me I have given to them, and they have received them and know in truth that I came from you; and they have believed that you sent me'. 
able to recognise Jesus (Jn 1:32-34). The point is that nobody has the inherent ability to recognise God's Son (Jesus), the one whom God sent. The event of revelation begins when God communicates with the Baptist what to look for. This established the environment in which the Spirit will work. For John the Spirit reveals Jesus and makes him known. When people come to know Jesus and receive divine life (Jn 1:13), this reveals the work and experience of the Spirit (cf. Koester 2008:135; cf. also Thistleton 2013:141). ${ }^{29}$

The function of the Spirit in fostering faith in Jesus is described by John as a new birth (Jn 1:12-13; 3:5, 8). The transition between the realm of the flesh and that of the kingdom of God is called 'born ... of God' (Jn 1:12-13), 'born from above' (Jn 3:5) or 'born from the Spirit' (Jn 3:8). In 3:19-21, John describes this transition between these spheres as 'coming to the light'. Together the 'kingdom of God' and 'to come to the light' semantically define what it means to receive and experience 'eternal life'. For John then, faith in the Word ${ }^{30}$ and rebirth from the Spirit constitute a life-giving relationship with God (Koester 2008:137-138; cf. Borchert 1996:118). In Jesus' conversation with Nicodemus, the function of the Spirit is central in the first part, but the function of Jesus is in the second part. Just as it is necessary for people to be born again in or by the Spirit ('You must [ $\delta \varepsilon \tilde{]}]$ be born again', Jn 3:7), so is it necessary for the Son of Man to be lifted up ('[E]ven so must [ $\delta \varepsilon \tilde{u}]$ the Son of Man be lifted up', Jn 3:14): both are needed so that people might believe and experience this new life. This event, of rebirth, is a 'lived experience' of the divine that constitutes change in the life of the believer.

\section{Love in the familia Dei}

The second identity characteristic of God is his immense love for his Son and his children. ${ }^{31}$ A resemblance of love exists between the Father and the Son (Jn 3:35; 14:31). The Father loves the Son in a distinctive way. This love featured before

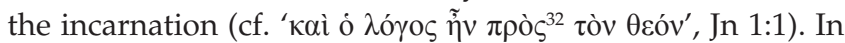
fact, John writes that the Father loved the Son prior to the

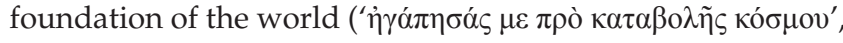
Jn 17:24). In 1:18, John also refers to the Son to be 'in the bosom of the Father' (cf. Koester 2008:49).

This mutual love between the Father and the Son that unites them and endorses the divinity of Jesus shows their acts towards one another. John understands the love between them 'as a bond of commitment'. This enabled Jesus to be obedient to the Father's will (Koester 2008:49). The Father's

\section{According to Mussner (1967:45-46), the Johannine Paraclete 'reveals' more of the exalted Christ from the post-resurrection perspective.}

30.In the prologue, John presented the Logos being independent of God, but also in

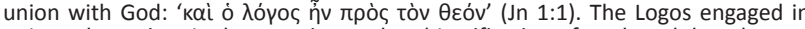
universal creation; it also constitutes the objectification of truth and drew human beings into the same union he enjoys with the Father, via his incarnation. To achieve this, Waetjen (2001:265) states, the Logos undertakes the role attributed

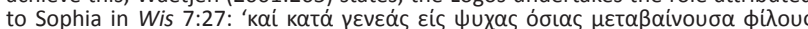

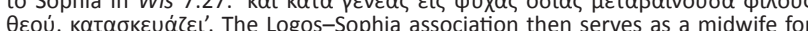
the birth of humans to become 'children of God' (Waetjen 2001:265).

31.The noun 'love' appears 57 times in John, more often than in the Synoptics combined. In addition, it appears 46 times in 1 John.

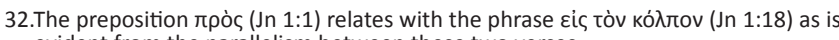
evident from the parallelism between these two verses. love for his Son is evident in him giving the Son responsibilities and the power to complete it. ${ }^{33}$ According to John, the Father's love for the Son caused the Father to put all things into the hands of the Son, showing him all that he himself is doing (Jn 3:35; 5:20). He also gives to Jesus the Spirit without measure to assist him to accomplish these tasks (Jn 3:34).

In John, Jesus expresses his responding love for the Father in his obedient actions of revelation and salvation. He also glorifies the Father. All this is a reflection of the unity between them. But John argues that the Son always and only does what the Father does. The Son does what the Father shows and tells him to do.

John accomplishes this by arguing that the work that Jesus does is in fact the very work of God - they are one. The unity between Father and Son constitutes a unity of love, speech, work, glorification and mission.

He is authorised and sent to fulfil a specific task on behalf of the Father who sent him; hence, 'the one who (Thompson 2014:158) obeys the Son is the one who works in full harmony with the Father (Thompson 2014:159).

When Jesus (the Son) washes the feet of the disciples, love is expressed as a self-giving service (Jn 13:1-5; see also Jn 3:16). This love culminated in the crucifixion where the Son revealed the Father's love. The love shared by the Father and Son is the love that also unites them. In the Farewell Discourses, Jesus expresses the reason why he has made the Father known. He asks the Father that his disciples should be drawn into the same relationship with God that he has had from all time: ${ }^{24}$

Father, I desire that they also whom You gave Me may be with Me where I am, that they may behold My glory which You have given Me; for You loved Me before the foundation of the world $\ldots{ }^{26}$ And I have declared to them Your name, and will declare it, that the love with which You loved Me may be in them, and I in them. (Jn 17:24, 26, NRSV).

The love that existed from the beginning (cf. Jn 1:1) 'between God and the Word, between the Father and the Son' has been issued into the human sphere (Moloney 2013:37-70;

\footnotetext{
33.In his writing, On Flight and Finding (103; see also 95), Philo refers to God as '[T]he

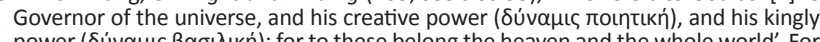

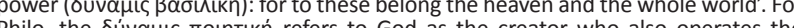

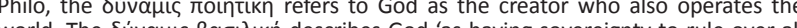

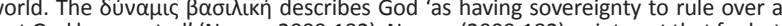
that God has created' (Neyrey 2009:182). Neyrey (2009:182) points out that for both Philo and the rabbis these two powers of God are connected with two names that refer to God in the Old Testament, namely, kúpıós [Lord] and $\theta \varepsilon o ́ c$ [God], according to the Septuagint. In John, these two powers are also associated or attached with Jesus. John's prologue attributed Jesus twice with creative power (Jn 1:3,10) and therefore refers to him as $\theta$ cóc in (Jn 1:1-3). In John 5, Jesus attributes to himself as 'creative' working on the Sabbath in which context he is assumed to be 'equal to God

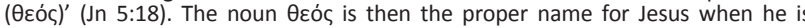
involved in creative activities. In a climactic place in John, Jesus is acclaimed

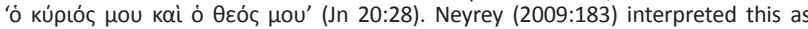
follows: '(1) Jesus is properly called "equal to God," (2) because he has God's two basic powers (creative and end-time): (3) he is properly called theos in virtue of basic powers (creative and end-time); ( 3 " he is properly called theos in virtue of having God's creative power and "Kyrios" in virtue of God's executive or end-time power. ...(5) for God gave him these powers and so wants Jesus to be honored even as God is honored'. Bauckham (2008:26-40) complements this statement of Neyrey He has pointed out that 'Alongside identifications of God in his covenant relationship with Israel, there are also characterizations of his identity by reference to his unique relationship to the whole of reality: most especially, that he is Creator of all things and sovereign Ruler of all things' (Bauckham 2008:31).
} 
cf. Keener 2002:1064). The Spirit-Paraclete makes it possible for Jesus to claim unity between himself and the Father and himself and a disciple: 'that the love with which You loved Me may be in them, and I in them' (Jn 17:26, NRSV).

Similarly, should the obedient actions of believers reflect on their love for Christ (and the Father). The axiom, '[i]f you love me, you will keep my commandments' (Jn 14:15; cf. Jn 14:21), relates to, '[ $t$ ]hose who love me will keep my word' (Jn 14:23). It occurs frequently in Chapters 14 and 15 and constitutes this parallelism:

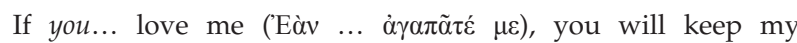
commandments. (Jn 14:15)

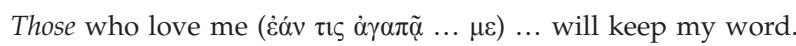
(Jn 14:23).

Subsequently, two assumptions can be made: (1) Jesus sets an example: 'I do as the Father has commanded me' (Jn 14:31). His devoted relationship and unity with God reveal his

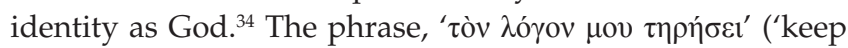
my commandments', Jn 14:23), designates the effect and unity of their affiliation. (2) All this results in the reality that both the Son's and the disciples' love will be equivalent to the Father's love. This implies an obedience from Jesus' disciples (the children of God in the familia Dei) equivalent to the obedience of Jesus to the Father's commandments. The love of the disciples has to resound the love of Jesus because God's love determines the nature of this love. This implies that the disciples' love is a manifestation and experience of God's love. Their conduct must equate the conduct of Jesus in a particular situation (Van der Merwe 1996:448; Van der Watt 1992:83). This will characterise their unity. Van der Watt (1992; see also Van der Merwe 1996:454) correctly signifies that through Jesus' obedience:

[T]o the will of the Father $(4: 34 ; 5: 30 ; 8: 38 ; 8: 29)$, the will of the Father has then become his will and his will consequently became the same as the will of the Father. If this argument is true, then it implies that the commands of Jesus to his disciples relate to the will of God for him, Jesus. Then, the will of the Father for them will be similar to the will of the Father for Jesus. (p. 86)

What a love experience will this not be for the disciple?

The love shared by the Father and Son is given to the children of God through the life and death of Jesus (cf. Koester 2008:49). What happens then is that the lived experiences of God's love make it possible for believers to become connected to both the Father and Son and to become part of a community shaped by divine love (Jn 17:23-26; Koester 2008:50). The result is to identify the believers' love for God as one which fosters divine 'lived experiences' when the believers love one another. The obedience to express this divine love through words and deeds will foster 'lived experiences' of the divine and divine love by those who love as well as those who are loved.

34.Jesus uses here his obedience to the commandments of the Father as an example rather than as a comparison ( $\kappa \theta \Theta \dot{\omega} c)$ for his disciples to imitate him. Jesus' conduct rather than as a comparison ( $\alpha \theta \dot{\omega} \varsigma_{\text {) }}$ for his disciples to imitate him. Jesus' conduct
is actually the manifestation of the Father's will (Jn $4: 34 ; 6: 38$ ) as well as his oneness or unity with the Father.

\section{Unity in the familia Dei}

The third identity characteristic of the divine is the unity within the Trinity. Three fundamental resources in John for the understanding of Jesus' divine identity and unity with the Father are the Prologue, formulas of immanence and expressions of unity.

Prologue: Eight aspects in the prologue are pointed out to strengthen Jesus' (the Son's) divine identity and unity with God (the Father).

1. A parallelism exists between $1: 1$ and 1:18, which indicates the position, function and status of Jesus as deity:

John 1:1

John 1:18

'In the beginning ${ }^{35}$ was Knowledge 'No one has seen the Word'

'and the Word was with Position 'who is in the bosom God'

'and the Word' Function 'He has declared

Him'

'was God' (also Jn 5:18; Status 'The one and only 10:33; 20:28)

God/Son'

2. The Word participated in the creation of the universe, '[a]ll things were made through him' (Jn 1:3; see also Jn 1:10). The Father is implied as the creator and the Son as instrumental in the creation process. ${ }^{36}$

3. In 1:4, John also introduces the Word as the one who already possesses the life of the Father, 'In Him was life, and the life was the light of men'.

4. The Word was the true Light which gives light to every man (Jn 1:9) because in him was light ('In Him was life, and the life was the light of men', Jn 1:4).

5. The Word became flesh (Jn 1:14) and dwelt (was life, ${ }^{37}$ among humans).

6. He is referred to as being the 'one and only Son/God'

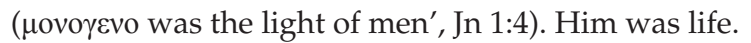

7. '[G]race and truth came through Jesus Christ' (Jn 1:17).

8. 'Nobody has ever seen God, but he is in the bosom of the Father and has declared the Father'.

According to this analysis, the divine nature of the Logos is then evident in his activities in creation (Jn 1:1-5) together with the Father, in revelation (Jn 1:5, 9-12, 18) to reveal the Father and redemption (Jn 1:12-14, 16-17; Beasley-Murray 1999:11; see also Cowan 2006:116) to glorify the Father (cf. Jn 17:1-8).

The first verse of the prologue contains three basic and important affirmations that are fundamental to Christian theology (Borchert 1996:102). The first theological affirmation links God and the beginning. It also links the Logos (Word) with the beginning. The second theological affirmation

35.The phrase 'In the beginning' is not temporal but ontological (cf. Lossky 1978:36).

36.Thompson (1999:76; see also Bauckham 2008:34, 66) refers to Jewish authors who regard the exclusivity of the God of Israel as sojourned in the whole of God's creation. For verification, she refers to two references where God is depicted as creation. For verification, she refers to two references where God is depicted as
'the Lord God who gives life to all things' (Jos. Asen. 8:4), the 'Creator of all things' 'the Lord God who gives life to all things' (Jos. Asen
who gives 'life and breath' (2 Macc 1:24; 7:23).

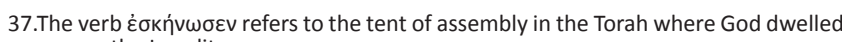
among the Israelites. 
emphasises an identity difference between the Word and God, and the third affirmation interconnects or unifies the Word and God (Borchert 1996:102). In reference to John 1:1, Westcott and Westcott (1908) allege that:

No idea of inferiority of nature is suggested by the form of expression, which simply affirms the true deity of the Word.... Thus we are led to conceive that the divine nature is essentially in the Son, and ... that the Son can be regarded, according to that which is his peculiar characteristic, in relation to God as God. (p. 3)

According to Köstenberger (2004:25; Ridderbos 1997:25), ' $t]$ he focus of this verse is to show the Word's preexistence'.

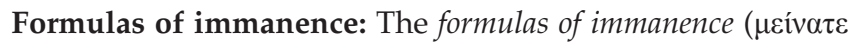
$\dot{\varepsilon} v$, $\dot{\varepsilon} v, \varepsilon \tilde{v})$ in John peak in 17:20-23, where Jesus makes the

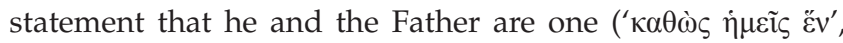

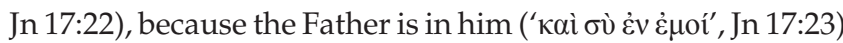

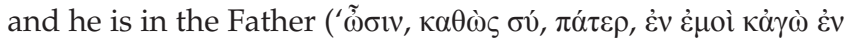
$\sigma o i^{\prime}$, Jn 17:21).

This oneness clearly indicates that both Jesus (the Son) and the Father can never be thought of apart from one another. As Van der Merwe (1996) opines:

The statement that Jesus is in the Father and the Father is in Jesus $(17: 21,22)$, describes a relationship in which the one cannot be without the other. Therefore, Jesus could tell his disciples that 'He who has seen Me has seen the Father' (14:9; also cf. 12:45). (pp. 432-433)

Expressions of unity: The audience of John knows that a close affiliation and unity exist between the Father and Son. '[F]or whatever He [the Father] does, the Son also does in like manner' (Jn 5:23); that the one 'who does not honour the Son does not honour the Father' (Jn 5:23); 'I and My Father are one' (Jn 10:30); 'No one comes to the Father except through Me' (Jn 14:6); 'If you had known Me, you would have known My Father also' (Jn 14:7); 'He who has seen Me (Jesus) has seen the Father' (Jn 14:9); 'He who hates Me hates My Father also' (Jn 15:23). In John 17:10 Jesus' possessions in relation to the Father's possessions are clearly spelt out: 'All mine are yours, and yours are mine'.

Jesus refers several times in John to himself as 'I am' (Jn 4:26, 6:20, 8:24, 8:28, 8:58, 13:19, 18:15, 18:6 and 18:8). Simmons (1988:100-101) understands Jesus' use of the 'I am' formula as an association with the divine Shekinah, which illuminated the wilderness trek and where God was present among his children. This constitutes his existence to transcend time. Therefore, the Jews understood his 'I $a m^{\prime}$-references as a declaration to make himself equal with God. This is verified in John 8:58 where Jesus claimed to be divine and preexistent. Finally, Thomas refers to Jesus as 'My Lord, and my God'. From the above discussion, it is clear that the Son and the Father are in one another (Jn 17:21-23).

The unity between the divine and the disciples is explained in John 15 (and also Jn 17:21-23), where Jesus requests his

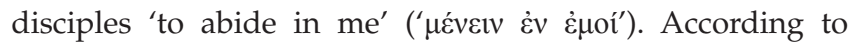

Neyrey (2007:259), 'abide' describes how the Father and his Son relate ('The Father abides in me', Jn 14:10) and how the disciples must abide in Jesus (Jn 15:4, 9-10). Ridderbos (1997:517) interprets the nature of 'abide' to be more advanced $^{38}$ in Chapter 15 owing to its association with the vine image. John $15: 4-5$ is highly significant for this investigation. Jesus invites his disciples to abide in him and he in them, for them to 'bear much fruit' (Jn 15:5). The disciples of Jesus have already started to abide in him the moment they started following Jesus. 'To abide in Jesus' is faithfulness to him. He is the primary source through which the disciples can bear much fruit to glorify the Father. In other words, abiding in Jesus comprises obedience to his word. The Spirit-Paraclete constitutes his presence and accomplishes it (Ridderbos 1997:517). A description of this unity culminates in John 17:21-23. ${ }^{39}$ Here, John indicates that the manifested results of the unity among the disciples and their unity with Jesus and God will be that the world will believe (Jn 17:21) and know (Jn 17:23) that the Father has sent the Son.

John also wrote that the Spirit will abide with (' $\mu \varepsilon \theta$ ' $\dot{v} \mu \tilde{\omega} \nu$... $\tilde{\eta ்}^{\prime}$, Jn 14:16) the disciples and dwell with them and will be in them (' $\pi \alpha \rho '$ ' that the disciples' obedience to the commands of Jesus (that equals the 'will of God' and 'abide in') will foster experiences (awareness) of the presence of God via the Spirit, who will remind the believers what Jesus had said and guide them to fulfilment. To abide in Jesus will glorify God.

\section{Glorification in the familia Dei}

The fourth identity characteristic concerns the glory of God (and Jesus). ${ }^{40}$ John 17 plays a fundamental role in the understanding of the Trinity from the glory perspective. The $\omega \rho \alpha$ (Jn 17:1) of Jesus is interpreted by John to be the required will of God. This $̋ \rho \alpha$ is the culmination of the ministry of Jesus (Ramm 1963:43). For Perkins (1978:14), quoted by Mahoney (2011:37), 'the plot of the Gospel is focused on the "hour" of Jesus' glorification, his return to the Father at the crucifixion' ${ }^{41}$ It was a divine essential. Jesus had to die $(\delta \varepsilon \tilde{i}$, Jn $3: 14 ; 12: 34)$. God had to destine the time. A study of $\omega \rho \alpha$ (and also kaıpó in Jn 7:6) indicates that the life and ministry of Jesus were entirely 'determined and defined by the will of the Father' (Ramm 1963:41). The enemies of Jesus could not arrest him prior to his hour of crucifixion. The course of his life was determined by $\dot{\eta} \omega \rho \alpha$ of the Father and advanced

38.The high frequency ( 29 times) of the verb $\mu \varepsilon v \varepsilon v$ [to abide] in Chapter 15 creates emphasis and clarity.

39. ${ }^{21}$ that they all may be one, as You, Father, are in Me, and I in You; that they also may be one in Us, that the world may believe that You sent Me. ${ }^{22}$ And the glory which You gave Me I have given them, that they may be one just as We are one: ${ }^{2}$ $\mathrm{I}$ in them, and You in Me; that they may be made perfect in one, and that the world may know that You have sent Me, and have loved them as You have loved Me'.

40.The glory motif (using $\delta o ́ \xi \alpha / \delta \circ \xi \alpha \dot{\alpha} \zeta \omega$ ) is used 13 times in connection with the glory of God '(Jn 9:24; 11:4,40; 12:28; 13:31; 14:13; 15:8; 17:1,4; 21:19). The $\delta$ ó $\alpha$ of God comes from the Jews (Jn 9:24), from the disciples (Jn 15:8; 21:19), but especially from Jesus (Jn 7:18; 12:28 by implication; 13:31, 32; 17:1, 4)' (Van der Merwe $2002 \cdot 228$ ). The glory motif is used 19 times in connection with the glory of Jesus 2002:228). The glory motif is used 19 times in connection with the glory of Jesus (Jn $1: 14 ; 2: 11 ; 7: 39 ; 8: 54 ; 11: 4 ; 12: 16,23,41 ; 13: 31,32 ; 16: 14 ; 17: 1,5,10,22,24)$ The $\delta$ o $\xi \alpha$ of Jesus comes from his disciples (Jn 17:10), the Spirit (Jn 16:14) and the (Jn 2:11; 11:4)' (Van der Merwe 2002:228-229).

41.In John 7:39, 12:16, 23 and 17:1, סó $\alpha$ is noticeably related with the death of Jesus. At the cross he revealed both his identity and that of God (Jn 1-5). 
through the cross (Jn 13:1; Ramm 1963:41f). This significant event was critical to redeem mankind. In this redeeming event, the world would become cognisant of the true identity of Jesus (the Christ, the Son of God - Jn 20:31) and also the true identity of God (the loving Father, Jn 3:16). The cross then does not constitute a revelation of glory but was the occasion for glorification (Ramm 1963:41). The phrase, 'غ่ $\lambda \dot{\eta} \lambda v \theta \varepsilon v \dot{\eta} \omega \rho \alpha^{\prime}$, generates the situation for the 'glorification' of both the Father and Son. Thus, the salvation experience constitutes the revelation experience.

John 17:1-5 is a separate unit within Chapter 17. The theme of glorification lies at the centre and constitutes a chiasm (Waldstein 1990:320). The verb ( $\delta$ o $\xi \alpha \dot{\zeta} \omega)$ occurs four times (all in the aorist) and the noun ( $\delta \delta \xi \alpha)$ only once. This chiastic structure emphasises how the soteriological events constitute the glory of both Jesus and the Father. The recurring occurrence of the verb ( $\delta$ o $\xi \alpha \dot{\alpha} \zeta \omega)$ facilitates insights into the interpretation and understanding of the discourse (Robbins 1996:8). From the above analysis, five chiasms (cf. Malatesta 1973:195f.) are derived:

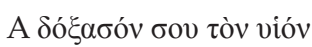

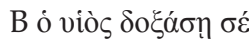

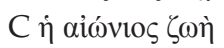

$\mathrm{B}^{\prime} \dot{\varepsilon} \gamma \omega \dot{\sigma} \sigma \varepsilon \dot{\varepsilon} \delta \delta^{\prime} \xi \alpha \sigma \alpha$

A' $\delta o ́ \xi \alpha \sigma o ́ v \mu \varepsilon \sigma u ́$

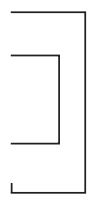

This chiastic pattern helps interpret $\delta$ o $\xi \alpha \dot{\zeta} \omega$ from the perspective where the Son is glorified $\left(\mathrm{A}-\mathrm{A}^{\prime}\right)$ and from the glorification of the Father $\left(B-B^{\prime}\right)$. From this pattern, it is evident that the 'glory' theme revolves around the 'eternal

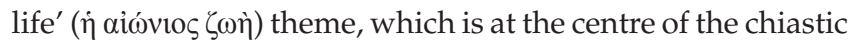
structure. Thus, both the glorifications of the Father and the

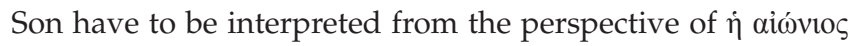

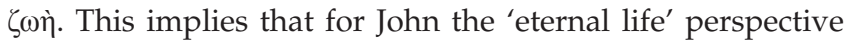
forms the main theological setting from which $\delta o \xi \alpha \dot{\zeta} \omega \omega$ is to be construed. ${ }^{42}$

A-A': The glorification of the Son: These components of the chiasm concern the $\delta o \xi \dot{\alpha} \zeta \varepsilon v$ of the Son which centres around its theological goal, 'îv ò viò $\delta o \xi \alpha ́ \sigma \eta ̣ ~ \sigma \varepsilon ́$ '. In this phrase, the 'glorification' of the Son concerns his exaltation on the $\operatorname{cross}^{43}$ (and corresponds with Jn 7:30; 8:20; 12:23) and signifies the beginning of his ascension to his Father (cf. Pamment 1983:14). Jesus' glorification is instrumental to the Father's glorification (Van der Merwe 2002:232).

42.'Scholars (Aalen 1976:45ff.; Brown 1971:503; Cook 1984:292; Kittel 1978:247ff; Kysar 2007:135; Painter 1975:50) agree that the Fourth Evangelist draws on the Old Testament idea of God's כָּבוֹ' (Van der Merwe 2002:233). This noun is used in the Hebrew scriptures to designate the manifestation of God. The revelation of God and the presence of God were realised through his mighty deeds in history. The presence of God implies glory.

43.John also uses another verb, namely ú raise up', and metaphorically 'to exalt'. It is used four times in Jesus' public teaching cise concerning the Son of $\operatorname{man}(\mathrm{Jn} 3: 14 ; 8: 28 ; 12: 32-34)$. By using the verb u $\psi \mathrm{o}$ ' $\omega$, John expresses that this uplifting on the cross is also Jesus' exaltation, relating the verb to be synonymous with the verb $\delta \circ \xi \alpha \zeta \omega$ (see Septuagint, e.g., Ex 15:2; is 33:10; Sir $43: 30$ ). In the Septuagint (Is $52: 13$, the Song of the Servant's suffering), the two verbs ú $\dot{\omega} \omega$ and $\delta \circ \xi \alpha \dot{\alpha} \zeta \omega$ have merged. It is suggested that John was influenced by this verse (see also LXX Is 4:2; Pamment 1983:156).
This remarkable salvation act reveals the identities of both the Father and the Son.

According to this paragraph (Jn 17:1-5), it is evident that the Father's work and Jesus' work complement one another; Jesus glorifies the Father through his complete obedience on the cross, and the Father glorifies Jesus in acknowledging his obedience. In John, Jesus' conduct is the product of his obedience to the Father (cf. Jn 3:34; 5:19ff.; 8:38; 17:8,14) through which he honours the Father (Carson 1991:355). According to John 17: $4-5$, Jesus is glorified in the light of what he has already accomplished - he has completed the mission assigned to him by

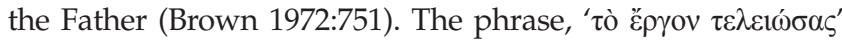
(Jn 17:4), constitutes the setting of his glorification. It (' $\tau$ ò हैpyov $\tau \varepsilon \lambda \varepsilon 1 \omega \sigma \sigma \varsigma^{\prime}$ ) was both the means to glorify the Father and the way to attain his glorification (Van der Merwe 2002:245).

However, in John 17:5, Jesus' glory resembles with the Father's glory. It verifies the pre-temporal existence of Jesus with the Father (cf. Jn 17:24; 17:5; Van der Merwe 2002:232). In John 17:5 (see also 17:24), ${ }^{44}$ John emphasises the glorious status that the Son will recommence, the glory that fits him (Jn 1:14b) and which he once experienced (see Jn 6:62; cf. Louw \& Nida 1980:529; see also Barrett 1978:504; Pamment

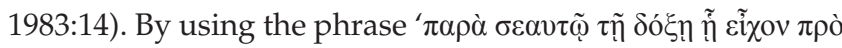

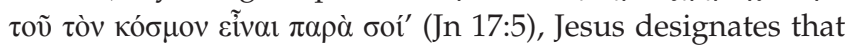
he wants to return to his original position prior to the incarnation ${ }^{45}$ to enjoy the eternal glory he enjoyed before the incarnation (cf. Jn 1:1) and resume fellowship with the Father (Bernard 1963:563; Brown 1972:742). This 'glorification' of the Son reveals his identity, his power to constitute redemption and elucidates his relationship with the Father.

John 5:23 (cf. Jn 8:19) is probably the most significant statement in John about Jesus' divinity ('so that [iv $\alpha$ ] all may honor the Son just as they honor the Father. Anyone who does not honor the Son does not honor the Father who sent him'). The Son must be honoured in the same way as the Father. ${ }^{46}$ The stature of the Son is verified when his glory is considered. Jesus manifested God's glory distinctively as the Son of the Father (Jn 1:14). His own glory shone in his miracles (Jn 2:11) and culminated on the cross. From John, it is evident

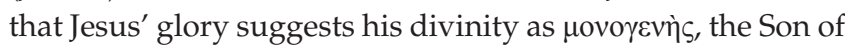
the Father. According to Isaiah (Jn 42:8; 48:11), Yahweh unconditionally declared that he would not give his glory to another. John, however, declared that even Isaiah saw the

44.In John 17:5, Jesus prays: 'And now, Father, glorify me in your presence with the glory which I had with you before the world was', and In John 1724 : 'Father, I desire that they also, whom you have given me, may be with me where I am, to behold my glory which you have given me in your love for me before the foundation of the world'.

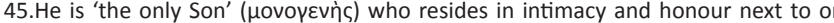
with the Father (Jn 1:18). Jesus often asserts his origination from God (Jn 3:13,31; $6: 33,38,46 ; 18: 37)$; he is from above, and not from this world (8:23); he has 'come from the Father into the world' (Jn 16:27, 28). For him the time has arrived (Jn 13-17) to leave this world and return to his Father in the world above (Jn 13:1. $16: 5,10 ; 16: 28)$.

46. Barrett (1978:260) confirms this: 'So complete is the identity and function and .Barrett (1978:260) confirms this: 'So complete is the identity and function and disregarding Jesus'. Ridderbos (1997:196-197) adds that 'God can be known and honoured in no other way than in the Son and that only in the revelation of the Son is the oneness of God manifest in its utter uniqueness' 
glory of Jesus in his vision (Jn 12:41). According to Hurtado (2003:380), John 'amounts to him being the one in whom God's glory is manifested, the unique human embodiment of God's glory on earth ... he is the glory of God manifest' (see also Ridderbos 1997:445).

B-B': The glorification of the Father: These components of the chiasm concern the $\delta$ o $\xi \alpha \dot{\zeta} \varepsilon ı v$ of the Father (Jn 17:1,4). On the one hand, through Jesus' crucifixion, ${ }^{47}$ the endorsement of $\dot{\eta} \alpha \dot{i} \omega \operatorname{vos} \zeta \omega \eta \dot{\eta}$, the Father is glorified (Jn 17:1, 2). On the other hand, in John 17:4 the Father is equally glorified by Jesus' obedience during his ministry, and the completion of

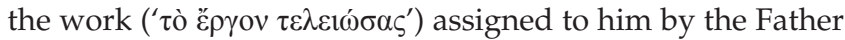
(Jn 17:6-8). The glorification of the Father and the Son cannot be disconnected. 'The glorification of the one closely relates to the glorification of the other, and the glory of one constitutes the glory of the other' (Van der Merwe 2002:233).

After Jesus reviewed the task the Father had assigned to him, he declared both his accomplishment of it (Jn 17:4) and his glorification of the Father through his obedience. Jesus' entire life revolved around obeying the Father to the glory of the Father. Jesus once said that his 'food is to do the will of the Father who sent him and to complete the Father's work' (Jn 4:34). Later in his ministry, he explained this statement referring to (Van der Merwe 2002):

$[T]$ hat his works are the works of God manifest in him (9:3); that the works he does prove his special unity and union with the Father (10:38); that the Father within him does his works (14:10). At the end of his Farewell Discourses he said that he had completed and fulfilled the work of the Father (' $\tau$ ò हैpyov $\tau \varepsilon \lambda \varepsilon i \omega ́ \sigma \alpha \varsigma^{\prime}, 17: 4$; cf. also 19:30), and explained it in 17:6-8 as the revelation of the Father's identity. (p. 244)

The purpose of Jesus' earthly ministry was to reveal the Father's identity and to reveal his personal divine glory (Lindars 1981:521). Jesus himself reveals and glorifies God. $\mathrm{He}$ is the visible manifestation of the invisible God, he has made the Father known (1:18; Van der Merwe 2002:244).

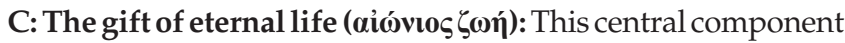
of the chiastic structure encompasses the aim (double iv $\alpha$ ) of both the glorification of the Son and that of the Father (Jn 17):

$[T]$ o give eternal life to all whom you have given him. ${ }^{3}$ And this is eternal life, that they may know you, the only true God, and Jesus Christ whom you have sent. (vv. 2-3)

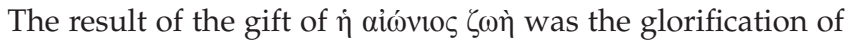
the Father and the Son. In this event, the Son was instrumental in the 'glorification' of the Father (Jn 17:1), and the Son was also 'glorified' (see Romanowsky 2005:101) in the revelation of his identity. Thus, the experiencing of 'eternal life' is a 'lived experience' of divine life and divine love, as well as the glorification of the divine: 'For God so loved the world that he gave his only Son' (Jn 3:16); 'No one has greater love than this, to lay down one's life for one's friends' (Jn 15:13).

47.John 17:1; see also John 12:23-24, 27-28; 13:31, 32 .
Spirit and disciples: The children of God will glorify the divine and experience divine Trinitarian fellowship when living in fellowship (unity) with one another (Jn 17:21-23), when being born from the Spirit (Jn 1:13; 3:5, 8), when bearing much fruit (Jn 15:9) and when experiencing Jesus' 'heavenly' glory when they will see him as he is (Jn 17:24). The realisation of the first three aspects in the lives of believers should also reveal the perichoresis of the divine Trinity in the familia Dei.

Unity: In John 17:22, Jesus gives the glory he received from the Father to his disciples and in John 17:21, 23 the disciples glorify God and experience this glorification through the unity among them and their unity with the divine. When this kind of unity realises, the world will believe (Jn 17:21) and know (Jn 17:23) that the Father has sent his Son into the world. According to Beasley-Murray (1999:302), this unity among Jesus' disciples is radical and fundamental: 'it is rooted in the being of God, revealed in Christ. The prayer "that they may be one" accordingly is defined as "that they may be in us"'.

Born of the Spirit: According to Jesus' teaching in the Farewell Discourses, the Paraclete will be operational among the disciples. Everyone born from the Spirit (from above) will see (experience) the $\delta$ ó $\xi \alpha$ of God (Jn 11:40), and after his resurrection the disciples of Jesus will see (experience) his $\delta o ́ \xi \alpha$ (Jn 17:24; Van der Merwe 2002:228). All those who believe in Jesus, following his example in obedience (keeping his commands, Jn 15:12-17) and those laying down their lives in loving service to other (Jn 13:13ff.) will not only glorify the Father and the Son (Jn 15:8; 17:10, 22 ), they will also experience this divine glory through the Spirit. The Spirit serves the mission of Jesus, just as Jesus served the will of the Father. Just as Jesus' mission was to glorify the Father, so here the mission of the Spirit will glorify Jesus (Jn 16:14; Borchert 2002:170).

Bear much fruit: In John 15:8, Jesus indicates that when his disciples bear much fruit the Father is glorified in them (Jn 12:23, 28, 31-32; 13:31-32; 17:1). For Keener (2002:II, 1003), the disciples should bear the fruit of love (Jn 13:35); when they bear 'much' fruit, 'they will lay down their lives in love as Jesus did' (Jn 12:24). ${ }^{48}$ The disciples glorify the Father directly because they abide in Jesus, the Vine and are obedient to him in the bearing of fruit by which they bring glory to the Father (Beasley-Murray 1999:173; Borchert 2002:146; Newman \& Nida 1993:484).

Consummation of Jesus' glorification: Twice in John 17, Jesus refers to the glory he experienced before the foundation of the world:

'So now, Father, glorify me in your own presence with the glory that I had in your presence before the world existed' (17:5);

48. Beasley-Murray (1999:273) interprets the 'much bearing of fruit' soteriologically. Neyrey (2007:254) interprets it as a person's deeds. Ridderbos (1997:518), in. Neyrey (2007:254) interprets it as a person's deeds. Ridderbos (1997:518), in more general sense, interprets the bearing of fruit as obeying the will of Jesus. Carson (1991:518) and Morris (1975:672) are also vague in their interpretation of 'bearing fruit'. 
'Father, I desire that those also, whom you have given me, may be with me where I am, to see my glory, which you have given me because you loved me before the foundation of the world'. (v. 24)

The children of God who partake, with the Son, to be loved by the Father (Jn 17:23), will probably also partake in the glory to which the Son is restored in consequence of his death/resurrection/exaltation (cf. Carson 1991:570). Borchert (2002:208) points out that the focal point of John 17:24 seems to be the experience of seeing Jesus' future glory - the glory which he experienced before the world existed. He requested the Father that his disciples could see his glory when they would reach their final destiny. Then they would absolutely realise the identity of Jesus. Jesus is thinking of the final consummation, when the disciples will see (experience) his true glory ${ }^{49}$ (Newman \& Nida 1993:545). In that ultimate encounter, 'when we will be like him, we will behold him as he is' (1 Jn 3:2; Borchert 2002:208).

This essay has endeavoured to understand the Johannine conceptualising and formulation of the Trinity. It has become clear that John can talk about a person within the Trinity only in terms of another person in the Trinity and their fellowship with one another. John understands the relationship between the 'children of God' and the 'divine' also in terms of the Trinity perspective. Experiencing the One is also experiencing the Other. He then uses family metaphorics to explain this fellowship in terms of the 'life', 'love', 'unity' and 'glorification' in the familia Dei.

\section{Conclusion}

John is most likely the most prolific and maverick book in the New Testament to defend, to substantiate the trinity concept and to experience the divine as Trinity in Christianity. The author of John was so convinced about the reality of the divinity of Jesus and the Spirit-Paraclete. He certainly would have divine Trinity so definite in his own life; therefore, he had to write this gospel, most probably (who knows) as supplementary and complementary to the synoptic gospels.

The familia Dei seems to be the most reasonable account to explain intelligibly the 'fellowship' within the divine Trinity in John as well as the 'lived experiences' of the divine Trinity in the lives of the children of God. Jesus and the Spirit should

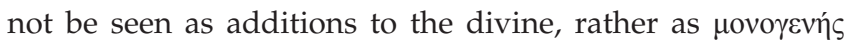

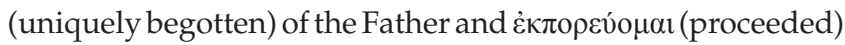
from the Father. They are identified each in relation (fellowship and immanence) to the other. This is the human way to try to talk about and understand the monotheistic God of the Bible, who nobody has ever seen. Only the divine Spirit gives life (reborn) to people, unites them with the divine, bestows the love of God on them and enables them to glorify God. All this work of the divine Spirit in the lives of believers enables them to experience fellowship with the divine Trinity.

49.Jesus twice refers to his glory which he had before the foundation of the world (Jn 17:5, 24)
The doctrine of the Trinity remains unfinished but continues to foster new enquiries, continuous research and 'lived experiences'. For those who concern themselves with it, and indeed find themselves still puzzling over it, it is an unending process of curiosity, learning and suffering. Christians can never give it up, but keep on seeking intelligibly to understand this conundrum of the Trinity.

\section{Acknowledgements Competing interests}

The author declares that they have no financial or personal relationships which may have inappropriately influenced them in writing this article.

\section{Author's contributions}

D.V.d.M. is the sole author of this article.

\section{Ethical considerations}

This article followed all ethical standards for carrying out research without direct contact with human or animal subjects.

\section{Funding information}

This research received no specific grant from any funding agency in the public, commercial, or not-for-profit sectors.

\section{Data availability statement}

Data sharing is not applicable to this article as no new data were created or analysed in this study.

\section{Disclaimer}

The views and opinions expressed in this article are those of the authors and do not necessarily reflect the official policy or position of any affiliated agency of the authors.

\section{References}

Aalen, S., 1976, 'Glory, honour', in C. Brown (ed.), Dictionary of New Testament theology, vol. II, pp. 44-52, Paternoster Press, Exeter.

Aune, D.E., 1972, The cultic setting of realized eschatology in Early Christianity, Brill, Leiden.

Bauckham, R., 2008, Jesus and the God of Israel. God crucified and other studies on the New Testament's Christology of divine identity, W.B. Eerdmans, Grand Rapids, MI.

Bauckham, R., 2009, God crucified and other studies on the New Testament's Christology of divine identity, Eerdmans, Grand Rapids, MI.

Barrett, C.K., 1978, The Gospel according to St John, SPCK, London.

Beasley-Murray, G.R., 1999, John (WBC 36), Word, Incorporated, Waco, TX.

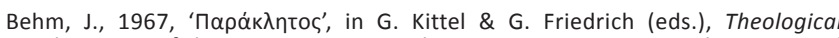
dictionary of the New Testament, vol. V, pp. 800-814, W.B. Eerdmans, Grand Rapids, MI.

Bernard, J.H., 1963, Gospel according to St. John. A critical and exegetical commentary, vol. 2, T\&T Clark, Edinburgh

Borchert, G.L., 1996, John 1-11, Broadman \& Holman Publishers, Nashville, TN.

Borchert, G.L., 2002, John 12-21, Boadman \& Holman Publishers, Nashville, TN.

Brown, R.E., 1971, The Gospel according to John (i-xii) (The Anchor Bible), Geoffrey Chapman, London.

Brown, R.E., 1972, The Gospel according to John (xiii-xxi) (The Anchor Bible), Geoffrey Chapman, London. 
Bultmann, R., 1971, The Gospel of John (Transl B. Blackwell), Basil Blackwell, Oxford.

Carson, D.A., 1991, The Gospel according to John, W.B. Eerdmans, Grand Rapids, MI.

Coetzee, J.C., 1993, 'The Gospel according to John: Introduction and theology', in A.B. Du Toit (ed.), Guide to the New Testament VI, pp. 40-77, N.G. Kerkboekhandel, Pretoria.

Combrink, H.J.B., 1980, 'Die Evangelie volgens Mattheus: Inleiding en Teologie', in A.B. Du Toit (ed.), Handleiding by die Nuwe Testament, vol. IV, pp. 62-83, N.G. Kerkboekhandel, Pretoria.

Cook, W.R., 1984, 'The "glory" motif in the Johannine corpus', Journal of the Evangelical Theological Society 27(3), 291-297.

Cowan, C., 2006, 'The father and son in the Fourth Gospel: Johannine subordination revisited', Journal of the Evangelical Theological Society 49(1), 115-135.

Danker, F.W. (ed.), 2000, Greek-English lexicon of the New Testament and other early Christian literature, in W. Bauer, F.W. Danker, W.F. Arndt \& F.W. Gingrich (eds.), 3rd edn., University of Chicago Press, Chicago, IL.

Davies, M., 1992, Rhetoric and reference in the Fourth Gospel, JSOT Press, Sheffield.

Dunn, J.D.G., 1989[1980], Christology in the making: An inquiry into the origins of the doctrine of the incarnation, 2nd edn., Student Christian Movement Press, London.

Du Plessis, I.J., 1980, 'Die Evangelie volgens Lukas: Inleiding en Teologie', in A.B. Du Toit (ed.), Handleiding by die Nuwe Testament, vol. IV, pp. 156-201, N.G. Kerkboekhandel, Pretoria.

Grayston, K.E., 1990, The Gospel of John, Trinity, Philadelphia, PA.

Gunton, C.E., 2003, Father, Son and Holy Spirit. Essays toward a fully Trinitarian theology, T\&T Clark, London.

Hurtado, L.W., 1998, One God, one Lord: Early Christian devotion and ancient Jewish monotheism, T\&T Clark, Edinburgh.

Hurtado, L.W., 2003, Lord Jesus Christ: Devotion to Jesus in earliest Christianity, W.B. Eerdmans, Grand Rapids, MI.

Juel, D.H., 1997, 'The Trinity in the New Testament', Theology Today 54(3), 312-324. https://doi.org/10.1177/004057369705400303

Käsemann, E., 1968, The Testament of Jesus. A study of the Gospel of John in the light of chapter 17, transl. G. Krodel, SCM, London.

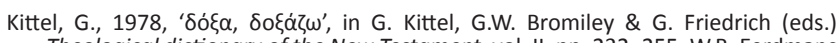
Theological dictionary of the New Testament, vol. II, pp. 232-255, W.B. Eerdmans, Grand Rapids, MI.

Keener, C., 2002, The Gospel of John: A commentary, Hendriksen Publications, Peabody, MA.

Koester, C.R., 2008, The word of life: A theology of John's Gospel, W.B. Eerdmans, Grand Rapids, MI.

Köstenberger, A., 2013, Encountering John: the Gospel in historical, literary and theological perspective, Baker Academic, Grand Rapids, MI.

Köstenberger, A.J., 1998, The missions of Jesus \& the disciples according to the Fourth Gospel, W.B. Eerdmans, Grand Rapids, MI.

Köstenberger, A.J., 2004, John, Baker Academic, Grand Rapids, MI.

Kysar, R., 2007, John the Maverick Gospel, Westminster John Knox Press, Louisville, KY.

Lindars, B., 1981, The Gospel of John (The New Century Bible Commentary), W.B. Eerdmans, Grand Rapids, MI.

Lossky, V., 1978, Orthodox-Theology: An introduction, St. Vladimir's Seminary Press, Crestwood, NY.

Louw, J.P. \& Nida, E.A., 1980, Greek-English lexicon of the New Testament based on semantic domains, United Bible Societies, New York.

Mahoney, J., 2011, 'The glory of God in St. John's Gospel', The Way 50(1), 21-37.

Malatesta, E., 1973, 'The spirit/Paraclete in the Fourth Gospel', Biblica 54(4), 539-550.

Moloney, F.J., 2013, Love in the Gospel of John: An exegetical, theological, and literary study, Baker Academic, Grand Rapids, MI.

Morris, L., 1975, The Gospel according to John (The New International Commentary on the NT), W.B. Eerdmans, Grand Rapids, MI.

Moshavi, A., 2015, 'Between dialectic and rhetoric: Rhetorical questions expressing premises in biblical prose argumentation', Vetus Testamentum 65, 136-151. https://doi.org/10.1163/15685330-12341182

Mussner, F., 1967, The historical Jesus in the Gospel of St. John, Quaestiones Disputatae 19, Burns \& Oates, London.

Neyrey, J.H., 2007, The Gospel of John, Cambridge University Press, Cambridge.
Neyrey, J.H., 2009, The Gospel of John in cultural and rhetorical perspective, W.B. Eerdmans, Grand Rapids, MI.

Newman, B.M. \& Nida, E.A., 1980, A translator's handbook on the Gospel of John, United Bible Societies, New York, NY.

Painter, J., 1975, John: Witness \& theologian, SPC, London.

Pamment, M., 1983, 'The Meaning of doxa in the Fourth Gospel', Zeitschrift für die Neutestamentliche Wissenschaft 74, 12-16. https://doi.org/10.1515/ zntw.1983.74.1-2.12

Perkins, P., 1978, The Gospel of John: A theological commentary, Franciscan Herald Press, Chicago, IL.

Ramm, B., 1963, Them he Glorified (A systematic study of the doctrine of glorification), W.B. Eerdmans, Grand Rapids, MI.

Reinhartz, A., 1999, 'Introduction: Father as metaphor in the Fourth Gospel', Semeia 85(1), 1-10.

Ridderbos, H., 1997, The Gospel of John: A theological commentary, W.B. Eerdmans, Grand Rapids, MI.

Robbins, V.K., 1996, Exploring the texture of texts: A guide to socio-rhetorical interpretation, Trinity Press International, Valley Forge, PA.

Romanowsky, J.W., 2005, 'When the Son of Man is lifted up: The redemptive power of the crucifixion in the Gospel of John', Horizons 32(1), 100-116. https://doi. org/10.1017/S0360966900002218

Schnackenburg, R., 1982, The Gospel according to St. John, vol. III, Burns \& Oates, London.

Shillington, V.G., 2012, 'The Spirit-Paraclete as Jesus' alter ego in the Fourth Gospe (John 14-16)', Vision (Spring), 31-39.

Simmons, B.E., 1988, 'A Christology of the "I Am" sayings in the Gospel of John', The Theological Educator 38(1), 94-103.

Spinks, B.D., 2008, The place of Christ in liturgical prayer. Trinity, Christology liturgical theology, Liturgical Press, Collegeville, PA.

Stamatović, S., 2016, 'The meaning of perichoresis', Open Theology 2, 303-323. https://doi.org/10.1515/opth-2016-0026

Strauss, M., 2007, Four portraits, one Jesus: A survey of Jesus and the Gospels, Zondervan, Grand Rapids, ML.

Talbert, C.H., 1992, Reading John. Reading the New Testament, Crossroad, New York.

Thistleton, A.C., 2013, The Holy Spirit, in biblical teaching through the centuries and today, W.B. Eerdmans, Grand Rapids, MI.

Thompson, M.M., 1999, 'The living father', in A. Reinhartz (ed.), God the Father in the Gospel of John, Semeia 85, pp. 19-31, Society of Biblical Literature, Atlanta, GA.

Thompson, M.M., 2001, The God of the Gospel of John, W.B. Eerdmans, Grand Rapids, MI.

Thompson, M.M., 2014, 'The Gospel of John in early Trinitarian thought: The unity of God in John, Irenaeus and Tertullian', Journal of Early Christian History 4(2), 154-166. https://doi.org/10.1080/2222582X.2014.11877309

Turner, M., 1996, The Holy Spirit and spiritual gifts then and now, Paternoster, Carlisle.

Van der Merwe, D.G., 1996, 'Discipleship in the Fourth Gospel', Unpublished doctoral thesis, University of Pretoria, Pretoria.

Van der Merwe, D.G., 1998, 'John 17: Jesus assigns his mission to his disciples', Skrifen Kerk 19(1), 115-127. https://doi.org/10.4102/ve.v19i1.1157

Van der Merwe, D.G., 2002, 'The glory-motif in John 17:1-5', Verbum et Ecclesia 23(1), 226-249. https://doi.org/10.4102/ve.v23i1.1250

Van der Merwe, D.G., 2014, 'Old Testament spirituality in the Gospel of John', Verbum et Ecclesia 35(1), 1-9. https://doi.org /10.4102/ve.v35i1.837

Van der Watt, J.G., 1992, 'Julle moet mekaar liefhê: Etiek in die Johannesevangelie', Scriptura S9A, 74-96.

Van der Watt, J.G., 2000, The family of the King. Dynamics of metaphor in the Gospel according to John, Brill, Leiden.

Vorster, W.S., 1980, 'Die Evangelie volgens Markus: Inleiding en Teologie', in A.B. Du Toit (ed.), Handleiding by die Nuwe Testament, vol. IV, pp. 109-156, N.G. Kerkboekhandel, Pretoria.

Waetjen, H.C., 2001, 'Logos $\pi \rho$ ò tòv $\theta \varepsilon o ́ v$ and the objectification of truth in the prologue of the Fourth Gospel', The Catholic Biblical Quarterly 63(2), 265-286.

Waldstein, M., 1990, 'The mission of Jesus and the disciples in John', Communio: International Catholic Review 17(3), 311-333.

Weiss, J., 1937, The history of primitive Christianity, vol. 1, MacMillan, London.

Westcott, B.F. \& Westcott, A. (eds.), 1908, The Gospel according to St. John. Introduction and notes on the Authorized version, J. Murray, London. 